\title{
Article
}

\section{The Effect of Meat and Bone Meal (MBM) on Crop Yields, Nitrogen Content and Uptake, and Soil Mineral Nitrogen Balance}

\author{
Anna Nogalska *(D) and Aleksandra Załuszniewska
}

Citation: Nogalska, A.;

Załuszniewska, A. The Effect of Meat and Bone Meal (MBM) on Crop Yields, Nitrogen Content and Uptake, and Soil Mineral Nitrogen Balance. Agronomy 2021, 11, 2307. https:// doi.org/10.3390/agronomy11112307

Academic Editors: Othmane Merah, Purushothaman

Chirakkuzhyil Abhilash,

Magdi T. Abdelhamid, Hailin Zhang and Bachar ZEBIB

Received: 2 November 2021

Accepted: 13 November 2021

Published: 15 November 2021

Publisher's Note: MDPI stays neutral with regard to jurisdictional claims in published maps and institutional affiliations.

Copyright: (c) 2021 by the authors. Licensee MDPI, Basel, Switzerland. This article is an open access article distributed under the terms and conditions of the Creative Commons Attribution (CC BY) license (https:// creativecommons.org/licenses/by/ $4.0 /)$.
Department of Agricultural and Environmental Chemistry, Faculty of Agriculture and Forestry, University of Warmia and Mazury in Olsztyn, 10-719 Olsztyn, Poland; aleksandra.zaluszniewska@uwm.edu.pl * Correspondence: anna.nogalska@uwm.edu.pl; Tel.: +48-895-233-250

\begin{abstract}
A long-term (six year) field experiment was conducted in Poland to evaluate the effect of meat and bone meal (MBM), applied without or with mineral nitrogen (N) fertilizer, on crop yields, $\mathrm{N}$ content and uptake by plants, and soil mineral $\mathrm{N}$ balance. Five treatments were compared: MBM applied at 1.0, 1.5, and 2.0 $\mathrm{Mg} \mathrm{ha}^{-1}$, inorganic NPK, and zero-fert check. Mineral N accounted for $100 \%$ of the total $\mathrm{N}$ rate $\left(158 \mathrm{~kg} \mathrm{ha}^{-1}\right)$ in the NPK treatment and $50 \%, 25 \%$, and $0 \%$ in MBM treatments. The yield of silage maize supplied with MBM was comparable with that of plants fertilized with NPK at $74 \mathrm{Mg} \mathrm{ha}^{-1}$ herbage ( $\left.30 \% \mathrm{DM}\right)$ over two years on average. The yields of winter wheat and winter oilseed rape were highest in the NPK treatment $\left(8.9 \mathrm{Mg} \mathrm{ha}^{-1}\right.$ grain and $3.14 \mathrm{Mg} \mathrm{ha}^{-1}$ seeds on average). The addition of $25 \%$ and $50 \%$ of mineral $\mathrm{N}$ to MBM had no influence on the yields of the tested crops. The $\mathrm{N}$ content of plants fertilized with MBM was satisfactory (higher than in the zero-fert treatment), and considerable differences were found between years of the study within crop species. Soil mineral $\mathrm{N}$ content was determined by $\mathrm{N}$ uptake by plants rather than the proportion of mineral $\mathrm{N}$ in the total $\mathrm{N}$ rate. Nitrogen utilization by plants was highest in the NPK treatment $(58 \%)$ and in the treatment where mineral $\mathrm{N}$ accounted for $50 \%$ of the total $\mathrm{N}$ rate $(48 \%)$.
\end{abstract}

Keywords: maize; wheat; rape; soil; nitrogen balance; animal meal; mineral nitrogen

\section{Introduction}

At present, waste management is one of the most important environmental issues worldwide. Alternative fertilizers based on by-products and biomass of various origin have been developed and applied to recycle valuable nutrients in food systems. Meat and bone meal (MBM) can be a viable alternative to natural, organic and mineral nitrogen (N), and phosphorus (P) fertilizers because it is rich in $\mathrm{N}$ (approximately $80 \mathrm{~g} \mathrm{~kg}^{-1}$ ), $\mathrm{P}$ (approximately $50 \mathrm{~g} \mathrm{~kg}^{-1}$ ), calcium-Ca (approximately $100 \mathrm{~g} \mathrm{~kg}^{-1}$ ), micronutrients, and organic matter (approximately $700 \mathrm{~g} \mathrm{~kg}^{-1}$ ) [1,2]. During the decomposition of organic compounds from MBM, some nutrients are released immediately, whereas others (in particular N) are temporarily immobilized by soil microbes, which largely prevents $\mathrm{N}$ losses. In MBM, $\mathrm{N}$ is present in the form of protein compounds, and it is released into the soil through mineralization, becoming available to plants already in the first year after application [1,3-6]. The rate of this process is determined by various environmental factors, and it may vary across years and seasons. Despite the fact that $\mathrm{N}$ compounds account for only $80 \mathrm{~g} \mathrm{~kg}^{-1}$ of the $\mathrm{MBM}$ and that mineral $\mathrm{N}$ accounts for only a minor portion of total $\mathrm{N}$, the low $\mathrm{C}: \mathrm{N}$ ratio of MBM (approximately 4) provides great potential for $\mathrm{N}$ mineralization [3]. Numerous studies have shown that MBM contributes to soil fertility, higher crop yields, and better quality of agricultural produce [1,4,7-15].

The NPK content of MBM does not correspond to the requirements of crops. Meat and bone meal has a low content of potassium-K (approximately $3.5 \mathrm{~g} \mathrm{~kg}^{-1}$ ), which should be supplied by other fertilizers. The high P content of MBM prevents it from fully 
meeting the $\mathrm{N}$ requirements of plants [5]. The N:P uptake ratios range from 4.5 to 9 in most crops; therefore, the application of MBM according to their $\mathrm{N}$ needs would lead to $P$ surplus in soil [7]. In turn, small doses of MBM are associated with lower yields and insufficient N supply to plants [6,9-12]. Organic fertilizers should be analyzed not only as a source of plant-available nutrients but also in view of their environmental impact [16]. The supply of nutrients required for adequate plant growth while minimizing nutrient losses to the environment is an essential part of sustainable nutrient management [17]. However, synchronizing $\mathrm{N}$ supply with crop $\mathrm{N}$ uptake poses a challenge when organic fertilizers are used. Therefore, a long-term (six-year) field experiment was performed to analyze the effects of MBM applied at three increasing doses without or with mineral $\mathrm{N}$ fertilizer on yield components and the chemical composition of maize, winter wheat, and winter oilseed rape, and on selected chemical properties of soil. The tested crops were selected due to their high economic importance around the world, including Poland. Long-term field experiments produce the most reliable results in terms of soil chemism and productivity, i.e., the yield and quality of agricultural crops. Some of the results relating to winter oilseed rape have already been published [18,19], as mentioned in the Materials and Methods section (Section 2.3). A research article describing the P content of plants and soil is currently being prepared for publication.

The objective of this study was to evaluate the effect of MBM combined with supplemental mineral $\mathrm{N}$ on crop yields (maize herbage, winter wheat grain and straw, winter oilseed rape seeds and straw), $\mathrm{N}$ content and uptake by plants, and soil mineral $\mathrm{N}$ content and balance.

\section{Materials and Methods}

\subsection{Experimental Site}

A small-area field experiment was conducted in six growing seasons of 2014 (maize), 2014/15 (winter wheat), 2015/16 (winter oilseed rape), 2016/17 (winter oilseed rape), 2017/18 (winter wheat), and 2019 (maize) at the Agricultural Experiment Station in Tomaszkowo (NE Poland), operated by the University of Warmia and Mazury in Olsztyn. The experiment, established on brown soil developed from loamy sand (Dystric Cambisol according to the World Reference Base-WRB) [20], had a randomized block design with four replications. The soil was slightly acidic $(\mathrm{pH}$ in $1 \mathrm{M} \mathrm{KCl}=5.61)$. The mineral $\mathrm{N}$ content of soil was $8.82 \mathrm{mg} \mathrm{kg}^{-1}$. The soil was highly abundant in magnesium- $\mathrm{Mg}\left(96 \mathrm{mg} \mathrm{kg}^{-1}\right)$, abundant in $\mathrm{K}\left(163 \mathrm{mg} \mathrm{kg}^{-1}\right)$, and moderately abundant in available $\mathrm{P}\left(65 \mathrm{mg} \mathrm{kg}^{-1}\right)$. The MBM used in this study was purchased from the Animal By-Products Disposal Plant SARIA Poland in Długi Borek near Szczytno, as it was classified as low-risk (category 3) material. The chemical composition of MBM, per kg dry matter (DM), was as follows: $963 \mathrm{~g}$ DM, $710 \mathrm{~g}$ organic matter, $280 \mathrm{~g}$ crude ash, $137 \mathrm{~g}$ crude fat, $78.7 \mathrm{~g} \mathrm{~N}, 45.3 \mathrm{~g} \mathrm{P}, 3.32 \mathrm{~g} \mathrm{~K}$, $100.1 \mathrm{~g} \mathrm{Ca} 6.8 \mathrm{~g} \mathrm{Na}$ and $2.0 \mathrm{~g} \mathrm{Mg} \mathrm{kg}^{-1}$. Soil $\mathrm{pH}$ measured in $\mathrm{H}_{2} \mathrm{O}$ was 6.3.

\subsection{Experimental Design}

The experimental treatments were as follows: (1) zero-fert; (2) inorganic NPK; (3) $1.0 \mathrm{Mg} \mathrm{ha}^{-1} \mathrm{MBM}+\mathrm{N}_{79}$; (4) $1.5 \mathrm{Mg} \mathrm{ha}^{-1} \mathrm{MBM}+\mathrm{N}_{40}$; (5) $2.0 \mathrm{Mg} \mathrm{ha}^{-1} \mathrm{MBM}$ (Table 1).

1. Zero-fert treatment: no fertilization.

2. Inorganic NPK treatment—only mineral fertilizers were applied: $\mathrm{N}-158, \mathrm{P}-45$, and $\mathrm{K}-145 \mathrm{~kg} \mathrm{ha}^{-1}$. Part of the $\mathrm{N}$ fertilizer $\left(30 \mathrm{~kg} \mathrm{ha}^{-1}\right)$ was applied presowing in the form of urea $(46 \% \mathrm{~N})$, and the remainder was top-dressed twice (in different growth stages of crops grown in rotation) at $80 \mathrm{~kg} \mathrm{ha}^{-1}$ and $48 \mathrm{~kg} \mathrm{ha}^{-1}$ in the form of ammonium nitrate $(34 \% \mathrm{~N})$. Phosphorus and $\mathrm{K}$ were applied presowing at $45 \mathrm{~kg} \mathrm{P} \mathrm{ha}^{-1}$ in the form of granular triple superphosphate $(20.1 \% \mathrm{P})$ and $145 \mathrm{~kg} \mathrm{~K} \mathrm{ha}^{-1}$ in the form of potassium chloride ( $49.8 \% \mathrm{~K})$.

3. Treatment No. 3-1.0 Mg ha $+\mathrm{MBM}+\mathrm{N}_{79}: 1.0 \mathrm{Mg} \mathrm{ha}^{-1} \mathrm{MBM}(79 \mathrm{~kg} \mathrm{~N}$ and $45 \mathrm{~kg} \mathrm{P})+$ $79 \mathrm{~kg} \mathrm{~N} \mathrm{ha}^{-1}$ in the form of urea $(46 \% \mathrm{~N})$ and $145 \mathrm{~kg} \mathrm{~K} \mathrm{ha}^{-1}$ in the form of potassium 
chloride $(49.8 \% \mathrm{~K})$ were applied presowing. Total $\mathrm{N}$ rate was $158 \mathrm{~kg} \mathrm{ha}^{-1}$. Mineral $\mathrm{N}$ accounted for $50 \%$ of the total $\mathrm{N}$ rate.

4. Treatment No. 4-1.5 $\mathrm{Mg} \mathrm{ha}^{-1} \mathrm{MBM}+\mathrm{N}_{40}: 1.5 \mathrm{Mg} \mathrm{ha}^{-1} \mathrm{MBM}(118 \mathrm{~kg} \mathrm{~N}$ and $68 \mathrm{~kg} \mathrm{P})$ $+40 \mathrm{~kg} \mathrm{~N} \mathrm{ha}^{-1}$ in the form of urea $(46 \% \mathrm{~N})+145 \mathrm{~kg} \mathrm{~K} \mathrm{ha}^{-1}$ in the form of potassium chloride $(49.8 \% \mathrm{~K})$ were applied presowing. Total $\mathrm{N}$ rate was $158 \mathrm{~kg} \mathrm{ha}^{-1}$. Mineral $\mathrm{N}$ accounted for $25 \%$ of the total $\mathrm{N}$ rate.

5. Treatment No. 5-2.0 $\mathrm{Mg} \mathrm{ha}^{-1} \mathrm{MBM}: 2.0 \mathrm{Mg} \mathrm{ha}^{-1} \mathrm{MBM}(158 \mathrm{~kg} \mathrm{~N}$ and $90 \mathrm{~kg} \mathrm{P})+$ $145 \mathrm{~kg} \mathrm{~K} \mathrm{ha}^{-1}$ in the form of potassium chloride $(49.8 \% \mathrm{~K})$ were applied presowing. Supplemental mineral $\mathrm{N}$ was not applied.

Table 1. Annual rates of nitrogen $(\mathrm{N})$, phosphorus $(\mathrm{P})$, and potassium $(\mathrm{K})$ applied with meat and bone meal (MBM) and mineral fertilizers $\left(\mathrm{kg} \mathrm{ha}^{-1}\right)$ to silage maize (2014 and 2015), winter wheat (2014/15 and 2017/18), and winter oilseed rape (2015/16 and 2016/17).

\begin{tabular}{ccccc}
\hline Treatment & $\mathbf{N}$ & $\mathbf{P}$ & $\mathbf{N}: \mathbf{P} * * * *$ & $\mathbf{K}$ \\
\hline 1. Zero-fert & 0 & 0 & 0 & 0 \\
2. Inorganic NPK & 158 & 45 & $1: 0.3$ & 145 \\
3. $1.0 \mathrm{Mg} \mathrm{MBM}+\mathrm{N}_{79}^{* *}$ & $158(79+79)$ & 45 & $1: 0.3$ & 145 \\
4. $1.5 \mathrm{Mg} \mathrm{MBM}+\mathrm{N}_{40}^{* *}$ & $158(118+40)$ & 68 & $1: 0.4$ & 145 \\
5. $2.0 \mathrm{Mg} \mathrm{MBM} * * * *$ & 158 & 90 & $1: 0.6$ & 145 \\
\hline
\end{tabular}

* Inorganic NPK-mineral fertilization; ${ }^{* *} \mathrm{MBM}+\mathrm{N}_{79}$-meat and bone meal with mineral nitrogen $\left(79 \mathrm{~kg} \mathrm{~N} \mathrm{ha}^{-1}\right)$ fertilizers; ${ }^{* * *} \mathrm{MBM}+\mathrm{N}_{40}$-meat and bone meal with mineral nitrogen $\left(40 \mathrm{~kg} \mathrm{~N} \mathrm{ha}{ }^{-1}\right)$ fertilizers; ${ }^{* * *} \mathrm{MBM}-\mathrm{meat}$ and bone meal fertilizer. Every year in the two, three, four, and five treatments applied mineral fertilization with potassium, the same dose of $145 \mathrm{~kg} \mathrm{~K} \mathrm{ha}^{-1}$. ${ }^{* * * * *} \mathrm{~N}: \mathrm{P}$-ratio of nitrogen to phosphorus in the fertilizer.

In all treatments excluding the zero-fert treatment, $\mathrm{N}$ was applied at $158 \mathrm{~kg} \mathrm{ha}^{-1}$. The differences between treatments consisted of decreasing the proportion of mineral $\mathrm{N}$ in the total N rate, from $100 \%$ in treatment No. 2 (inorganic NPK) through 50\% in treatment No. 3 $\left(1.0 \mathrm{Mg} \mathrm{MBM}+\mathrm{N}_{79}\right)$ and $25 \%$ in treatment No. $4\left(1.5 \mathrm{Mg} \mathrm{MBM}+\mathrm{N}_{40}\right)$ to $0 \%$ in treatment No. 5 (where only MBM was applied at $2.0 \mathrm{Mg} \mathrm{ha}^{-1}$ ) in order to widen a too narrow N:P ratio in MBM (1:0.6). The N:P ratio was widest in treatments No. 2 and 3 (1:0.3), and it reached 1:0.4 in treatment No. 4 and 1:0.6 in treatment No. 5 (MBM alone). In the third and fourth year of the study, $\mathrm{K}$ was applied presowing to winter oilseed rape at the same rate as to maize and winter wheat $\left(145 \mathrm{~kg} \mathrm{~K} \mathrm{ha}^{-1}\right)$ but in the form of two fertilizers-potassium chloride $(49.8 \% \mathrm{~K})$ and potassium sulfate $(41.5 \% \mathrm{~K}$ and $17 \% \mathrm{~S})$, at 72 and $73 \mathrm{~kg} \mathrm{~K} \mathrm{ha}^{-1}$, respectively. Potassium sulfate supplied $30 \mathrm{~kg} \mathrm{~S} \mathrm{ha}^{-1}$ to winter oilseed rape.

\subsection{Crop Plants}

In the first (2014) and sixth (2019) year of the experiment, maize cv. PIONIER P8488 was grown for silage. The preceding crop in the first year of the experiment was winter rye. Maize was sown on 5 May 2014 and 29 April 2019, and it was harvested on 22 and 24 September, respectively, in the milk-dough stage.

In the second $(2014 / 15)$ and fifth $(2017 / 18)$ year of the experiment, winter wheat cv. ARKADIA was grown. Winter wheat was sown on 25 September 2014 and 27 September 2017. Once-over harvest of grain and straw was carried out at the full ripe stage, with a combine harvester, on 4 August 2015 and 23 July 2018.

In the third (2015/16) and fourth (2016/17) year of the experiment, hybrid winter oilseed rape cv. SY SAVEO was grown. Winter oilseed rape was sown on 26 August 2015 and 25 August 2016. Once-over harvest of seeds and straw was carried out at the full ripe stage, with a combine harvester, on 18 July and 20 July, respectively. Some of the results relating to winter oilseed rape have already been published. Nogalska and Załuszniewska [18] analyzed macronutrient (N, P, K, Ca, and Mg) concentrations in winter oilseed rape seeds and straw and their uptake by aboveground biomass (two-year means). Załuszniewska and Nogalska [19] determined seed yield, thousand seed weight, protein yield, fat yield, fatty acid profile, and glucosinolate concentrations in winter oilseed rape (two-year means). In the present study, data on winter oilseed rape (seed yield, straw 
yield, $\mathrm{N}$ content and uptake) were subjected to one-way analysis of variance (ANOVA) separately for each year (Section 2.7), similarly to data on maize and winter wheat, which were grown in a six-year crop rotation system on the same 20 plots; plot size was $20 \mathrm{~m}^{2}$ $(4 \mathrm{~m} \times 5 \mathrm{~m})$. All cultivation and crop protection measures were applied at the optimum time in accordance with the recommendations for each crop species. At harvest, in each plot, yield was determined in terms of weight after threshing, moisture content was measured and adjusted to the standard moisture content for each crop species: maize herbage- $70 \%$, winter wheat grain $-14 \%$, winter oilseed rape seeds $-9 \%$, and straw- $-12 \%$. The results were expressed in terms of 1 ha.

\subsection{Chemical Composition of Plants}

One kg samples of maize herbage, winter wheat grain and straw, and winter oilseed rape seeds and straw were collected from each plot for chemical analyses. Plant samples, which had been dried to absolutely dry mass at $105^{\circ} \mathrm{C}$, weighted, and ground, were wet mineralized in concentrated sulfuric (VI) acid with hydrogen peroxide $\left(\mathrm{H}_{2} \mathrm{O}_{2}\right)$ as the oxidizing agent. Mineralized plant samples were analyzed for the content of total $\mathrm{N}$-with the sodium hypochlorite reagent (UV-1201 V spectrophotometer, Shimadzu Corporation Kyoto, Japan).

Nitrogen uptake $\left(\mathrm{UP}_{\mathrm{N}}, \mathrm{kg}\right.$ per ha) by the aboveground biomass of maize, winter wheat, and winter oilseed rape was calculated by multiplying herbage, grain, seed, and straw yields (on a DM basis) by $\mathrm{N}$ content. The utilization of $\mathrm{N}\left(\mathrm{UT}_{\mathrm{N}}\right)$ from mineral fertilizers and MBM was calculated using the following formula (\%):

$$
\mathrm{UT}_{\mathrm{N}}=\frac{\mathrm{UP}_{\mathrm{N}}-\mathrm{UP}_{0}}{\mathrm{~N}} \times 100 \%
$$

where:

$\mathrm{UT}_{\mathrm{N}}$-coefficient of $\mathrm{N}$ utilization (\%),

$\mathrm{UP}_{\mathrm{N}}-\mathrm{N}$ uptake with herbage, grain, seeds, and straw in the $\mathrm{N}$-fertilized treatment (kg per ha),

$\mathrm{UP}_{0}-\mathrm{N}$ uptake with herbage, grain, seeds, and straw in the zero-fert treatment (kg per ha),

$\mathrm{N}-\mathrm{N}$ rate $\left(\mathrm{kg} \mathrm{ha}^{-1}\right)$.

\subsection{Chemical Composition of Soil}

Each year after harvest, soil samples were collected at a depth of 0-30 $\mathrm{cm}$ to determine the content of ammonium $\mathrm{N}\left(\mathrm{N}_{-} \mathrm{NH}_{4^{+}}\right)$and nitrate $\mathrm{N}\left(\mathrm{N}_{-} \mathrm{NO}_{3^{-}}\right)$. Mineral $\mathrm{N}$ content was determined colorimetrically in fresh soil samples after extraction with $1 \% \mathrm{~K}_{2} \mathrm{SO}_{4}$ solution. The content of $\mathrm{N}_{-} \mathrm{NH}_{4}$ was determined with Nessler's reagent, and the content of $\mathrm{N}^{-} \mathrm{NO}_{3}{ }^{-}$ in soil was determined with phenoldisulfonic acid (UV-1201 V spectrophotometer, Shimadzu Corporation, Kyoto, Japan). Mineral $\mathrm{N}$ content $\left(\mathrm{N}_{\text {min. }}\right.$.) was calculated by summing up $\mathrm{N}-\mathrm{NH}_{4}+$ and $\mathrm{N}-\mathrm{NO}_{3}{ }^{-}$.

\subsection{Weather Conditions}

In the first (2014) and sixth (2019) year of the experiment, maize was grown for silage (Table 2). In both growing seasons (May-September), air temperatures were conducive to the growth of this thermophilic species. However, considerable rainfall deficiency during the growing season in the first year (precipitation was nearly two-fold lower than in the sixth year and 1.4-fold lower than the long-term average of 1981-2010) contributed to lower maize yield compared with the sixth year of the experiment. 
Table 2. Weather conditions in 2014-2019, and in the 1981-2010 reference period according to the Research Station in Tomaszkowo.

\begin{tabular}{|c|c|c|c|c|c|c|c|c|c|c|c|c|c|c|}
\hline \multirow[b]{2}{*}{ Month } & \multicolumn{7}{|c|}{ Mean Air Temperature $\left({ }^{\circ} \mathrm{C}\right)$} & \multicolumn{7}{|c|}{ Total Rainfall (mm) } \\
\hline & 2014 & 2015 & 2016 & 2017 & 2018 & 2019 & 1981-2010 & 2014 & 2015 & 2016 & 2017 & 2018 & 2019 & 1981-2010 \\
\hline January & -4.0 & 0.4 & -4.0 & -3.4 & -0.4 & -2.5 & -2.4 & 48.4 & 46.8 & 24.7 & 20.2 & 41.5 & 43.5 & 36.4 \\
\hline February & 1.2 & 0.5 & 2.3 & -1.4 & -4.6 & 1.8 & -1.7 & 8.1 & 6.8 & 57.1 & 47.6 & 3.1 & 31.5 & 24.2 \\
\hline March & 5.1 & 4.2 & 3.0 & 4.0 & -1.3 & 3.9 & 1.8 & 57.7 & 45.1 & 21.6 & 45.3 & 10.4 & 47.2 & 32.9 \\
\hline April & 8.8 & 6.7 & 7.4 & 5.7 & 10.8 & 8.0 & 7.7 & 26.0 & 38.2 & 28.8 & 59.1 & 33.5 & 0.0 & 33.3 \\
\hline May & 13.0 & 11.8 & 13.7 & 12.1 & 15.7 & 11.6 & 13.5 & 32.7 & 29.7 & 56.9 & 25.1 & 25.0 & 142.8 & 58.5 \\
\hline June & 14.4 & 15.5 & 17.1 & 15.7 & 17.2 & 20.2 & 16.1 & 50.8 & 29.5 & 69.3 & 74.5 & 53.7 & 120.6 & 80.4 \\
\hline July & 20.4 & 17.5 & 18.1 & 16.8 & 19.7 & 17.1 & 18.7 & 37.3 & 81.9 & 130.4 & 107.6 & 141.0 & 56.3 & 74.2 \\
\hline August & 17.1 & 19.8 & 17.1 & 17.4 & 19.2 & 18.5 & 17.9 & 86.1 & 14.3 & 70.4 & 63.1 & 44.6 & 55.9 & 59.4 \\
\hline September & 13.6 & 13.5 & 13.6 & 12.8 & 14.5 & 13.7 & 12.8 & 25.9 & 63.8 & 21.1 & 168.1 & 20.3 & 78.7 & 56.9 \\
\hline October & 8.7 & 6.1 & 6.1 & 8.7 & 8.7 & 9.8 & 8.0 & 15.1 & 19.4 & 104.3 & 114.9 & 84.7 & 33.4 & 42.6 \\
\hline November & 3.7 & 4.8 & 2.4 & 3.9 & 3.3 & 5.1 & 2.9 & 34.0 & 84.5 & 84.8 & 42.4 & 16.0 & 24.5 & 44.8 \\
\hline December & -0.4 & 3.4 & 0.8 & 1.8 & 0.9 & 2.7 & -0.9 & 61.8 & 56.6 & 41.1 & 35.2 & 58.8 & 38.2 & 38.2 \\
\hline Mean & 8.5 & 8.7 & 8.1 & 7.8 & 8.6 & 9.2 & 7.9 & 40.3 & 43.1 & 59.2 & 66.9 & 44.4 & 56.1 & 48.5 \\
\hline Sum & & & & & & & & 483.9 & 516.6 & 710.5 & 803.1 & 532.6 & 672.6 & 581.8 \\
\hline
\end{tabular}

In the second (2014/15) and fifth (2017/18) year of the experiment, winter wheat was grown. Adverse weather conditions were noted in the growing season of 2017/18, starting with excessive precipitation in September (2.6-fold higher than in 2014/15 and three-fold higher than the long-term average), which hampered sowing through sub-zero temperatures in February and March accompanied by considerable precipitation deficit (precipitation totals of $3.1 \mathrm{~mm}$ and $10.4 \mathrm{~mm}$, respectively), ending with too wet July (precipitation was 1.9-fold higher than the long-term average), which hindered harvest. The differences in weather conditions across years were reflected in differences in winter wheat yield.

Winter oilseed rape was grown (2015/16 and 2016/17) under adverse weather conditions. Drought in August 2015 hindered seed germination and seedling emergence. Precipitation was more than two-fold lower than the long-term average also in October 2015. The period of winter dormancy in 2015/16 considerably differed from the long-term pattern, the plants were not hardened off, and January was frosty, with no frost cover. The mean air temperature in March was $1.2{ }^{\circ} \mathrm{C}$ higher than the long-term average, but ground frost occurred between 10 and 20 March, which led to considerable crop yield losses. Winter oilseed rape grown in the growing season of 2016/17 was exposed to water deficit in May 2017 (precipitation was 2.3-fold lower than the long-term average), which affected yields. Finally, abundant precipitation in July 2016 (1.8-fold higher than the long-term average) and 2017 (1.5-fold higher than the long-term average) hindered harvest.

In conclusion, the six-year experimental period (2014-2019) was characterized by varied weather conditions, including uneven precipitation. Air temperatures during the growing seasons were around $0.6^{\circ} \mathrm{C}$ higher than the long-term average (1981-2010). High temperatures were expected to promote the growth and development of maize, which thrives at high temperatures, and the release of nutrients from MBM, but both processes were hampered by precipitation variability.

\subsection{Statistical Analysis}

Data on crops (yields of maize herbage, winter wheat grain and straw, winter oilseed rape seeds and straw, $\mathrm{N}$ content and uptake by plants) were processed by one-way ANOVA using STATISTICA 12 software [21].

Data on soil (content of $\mathrm{N}-\mathrm{NH}_{4^{+}}, \mathrm{N}_{-} \mathrm{NO}_{3^{-}}$and their sum $-\mathrm{N}_{\text {min. }}$ ) were processed by two-way repeated measures ANOVA using STATISTICA 12 software [21]; MBM dose was the fixed grouping factor (five fertilization treatments), and year of the study was the repeated measurement factor (six years).

The significance of differences between mean values (data on crops and soil) was estimated by Tukey's test at a significance level of $p<0.05$. 


\section{Results and Discussion}

\subsection{Crop Yield}

The yields of the tested crops were affected by fertilization (Table 3) and weather conditions during the growing season (Table 2). It should be noted that the proportion of mineral $\mathrm{N}$ in the constant annual rate of $\mathrm{N}\left(158 \mathrm{~kg} \mathrm{ha}^{-1}\right)$ in fertilized treatments was as follows: $100 \%$ in treatment No. 2 (inorganic NPK), 50\% in treatment No. $3(1.0 \mathrm{Mg}$ $\left.\mathrm{MBM}+\mathrm{N}_{79}\right), 25 \%$ in treatment No. $4\left(1.5 \mathrm{Mg} \mathrm{MBM}+\mathrm{N}_{40}\right)$, and $0 \%$ in treatment $\mathrm{No} .5$ (2.0 $\left.\mathrm{Mg} \mathrm{ha}^{-1} \mathrm{MBM}\right)$. The narrow N:P ratio in MBM (1:0.6) was widened to 1:0.4 and 1:0.3 by increasing the rate of supplemental mineral $\mathrm{N}$ added to MBM. Each tested crop was grown twice in a six-year crop rotation system to compare the responses of each species to the experimental factor (Table 3). Maize was grown for silage in the first (2014) and last (2019) year of the study. Herbage yields (30\% DM) varied over a wide range of $45.6 \mathrm{Mg} \mathrm{ha}{ }^{-1}$ in the zero-fert treatment to $86.2 \mathrm{Mg} \mathrm{ha}^{-1}$ in the $1.0 \mathrm{Mg} \mathrm{MBM}+\mathrm{N}_{79}$ treatment. No significant differences in maize yields were found between fertilized treatments, where maize yields were significantly higher than in the zero-fert treatment regardless of the rate of supplemental mineral N. It should be stressed that MBM was efficiently utilized by maize whose herbage yields in 2014 and 2019 were highest in the treatments where MBM was supplemented with mineral $\mathrm{N}$ at $25 \%$ of the total $\mathrm{N}$ rate $\left(68.6 \mathrm{Mg} \mathrm{ha}^{-1}\right)$ and $50 \%$ of the total $\mathrm{N}$ rate $\left(86.2 \mathrm{Mg} \mathrm{ha}^{-1}\right)$, respectively. The beneficial influence of MBM on crop yields was described by many authors $[1,3,4,7,14,22]$. However, low MBM doses were insufficient to meet the $\mathrm{N}$ requirements of plants due to the narrow N:P ratio, whereas high MBM doses led to an excessive accumulation of available $P$ in soil $[3,5,9-11,23,24]$. In the present study, maize yield was lower in the first year, which was characterized by considerable rainfall deficiency (precipitation was nearly two-fold lower than in 2019, Table 2) than in the last year (by $16.5 \mathrm{Mg} \mathrm{ha}^{-1}$ on average, Table 3). In a previous study, the amount of $\mathrm{N}$ (less than $150 \mathrm{~kg} \mathrm{ha}^{-1}$ ) supplied with MBM doses lower than $2.0 \mathrm{Mg} \mathrm{ha}^{-1}$ was insufficient to meet the $\mathrm{N}$ requirements of maize grown for silage [12]. When maize was grown for grain, the yield-forming effect of MBM applied at $1.5 \mathrm{Mg} \mathrm{ha}^{-1}$ each year [9] or at $3.0 \mathrm{Mg} \mathrm{ha}^{-1}$ every two years [10] was comparable with that of mineral fertilizers. Steppień et al. [15] reported that high MBM doses ( 2.0 and $3.0 \mathrm{Mg} \mathrm{ha}^{-1}$ ) exerted a significant residual effect on maize grain yields, which were also affected by weather conditions. A high residual fertilizing value of MBM, evidenced by high maize yields, was also observed by Chaves et al. [4] and Venegas [25].

Table 3. The effect of increasing MBM doses on the yield $\left(\mathrm{Mg} \mathrm{ha}^{-1}\right)$ of herbage $(30 \% \mathrm{DM})$, grain $(86 \% \mathrm{DM})$, seeds $(91 \%$ $\mathrm{DM})$, and straw $(88 \% \mathrm{DM})$ by crops in rotation.

\begin{tabular}{|c|c|c|c|c|c|c|c|c|c|c|}
\hline \multirow[t]{2}{*}{ Treatments } & \multirow{2}{*}{$\begin{array}{c}2014 \\
\text { Maize } \\
\text { Herbage }\end{array}$} & \multicolumn{2}{|c|}{$\begin{array}{l}2014 / 15 \\
\text { Winter } \\
\text { Wheat }\end{array}$} & \multicolumn{2}{|c|}{$\begin{array}{c}\text { 2015/16 } \\
\text { Winter Oilseed } \\
\text { Rape }\end{array}$} & \multicolumn{2}{|c|}{$\begin{array}{c}2016 / 17 \\
\text { Winter Oilseed } \\
\text { Rape }\end{array}$} & \multicolumn{2}{|c|}{$\begin{array}{l}\text { 2017/18 } \\
\text { Winter } \\
\text { Wheat }\end{array}$} & \multirow{2}{*}{$\begin{array}{c}2019 \\
\text { Maize } \\
\text { Herbage }\end{array}$} \\
\hline & & Grain & Straw & Seeds & Straw & Seeds & Straw & Grain & Straw & \\
\hline 1. Zero-fert & $45.6^{a}$ & $5.87^{\mathrm{a}}$ & $3.09^{\mathrm{a}}$ & $1.63^{\mathrm{a}}$ & $2.08^{a}$ & $1.79^{\mathrm{a}}$ & $2.04^{\mathrm{a}}$ & $3.38^{a}$ & $2.06^{\mathrm{a}}$ & $58.6^{\mathrm{a}}$ \\
\hline 2. Inorganic NPK* & $62.6^{\mathrm{b}}$ & $12.27^{\mathrm{c}}$ & $6.40^{\mathrm{b}}$ & $3.29^{c}$ & $3.95^{b c}$ & $2.99^{c}$ & $3.72^{b}$ & $5.53^{\mathrm{b}}$ & $3.54^{\mathrm{b}}$ & $79.2^{b}$ \\
\hline 3. $1.0 \mathrm{Mg} \mathrm{MBM}+\mathrm{N}_{79}{ }^{* *}$ & $62.9^{b}$ & $11.59 \mathrm{bc}$ & $6.53^{b}$ & $2.94^{b c}$ & $4.01^{\mathrm{c}}$ & $2.36^{\mathrm{b}}$ & $3.20^{b}$ & $5.22^{b}$ & $3.57^{b}$ & $86.2^{b}$ \\
\hline 4. $1.5 \mathrm{Mg} \mathrm{MBM}+\mathrm{N}_{40} * * *$ & $68.6^{b}$ & $11.02^{b c}$ & $6.28^{b}$ & $2.90^{b c}$ & $3.79 \mathrm{bc}$ & $2.49^{b}$ & $3.26^{\mathrm{b}}$ & $4.84^{\mathrm{b}}$ & $3.24^{b}$ & $83.2^{b}$ \\
\hline 5. $2.0 \mathrm{Mg} \mathrm{MBM} * * * *$ & $64.2^{b}$ & $10.71^{b}$ & $6.01^{b}$ & $2.58^{b}$ & $2.96^{\mathrm{ab}}$ & $2.41^{\mathrm{b}}$ & $3.11^{\mathrm{ab}}$ & $4.77^{\mathrm{ab}}$ & $3.02^{a b}$ & $79.1^{\mathrm{b}}$ \\
\hline Mean & 60.78 & 10.29 & 5.66 & 2.67 & 3.36 & 2.41 & 3.07 & 4.75 & 3.08 & 77.26 \\
\hline
\end{tabular}

* Inorganic NPK-mineral fertilization; ${ }^{* *} \mathrm{MBM}+\mathrm{N}_{79}$-meat and bone meal with mineral nitrogen $\left(79 \mathrm{~kg} \mathrm{~N}\right.$ ha $\left.{ }^{-1}\right)$ fertilizers; ${ }^{* * *} \mathrm{MBM}+$ $\mathrm{N}_{40}$-meat and bone meal with mineral nitrogen $\left(40 \mathrm{~kg} \mathrm{~N} \mathrm{ha}^{-1}\right)$ fertilizers; ${ }^{* * * *} \mathrm{MBM}-$ meat and bone meal fertilizer. Every year in the two, three, four, and five treatments applied mineral fertilization with potassium, the same dose of $145 \mathrm{~kg} \mathrm{~K} \mathrm{ha}^{-1}$. a, b, c, ab, bc-significant differences between means for fertilization (in columns), according to Tukey's test $(p<0.05)$.

Winter wheat was grown in the growing seasons of 2014/15 and 2017/18 (Table 3). Grain yields $(86 \% \mathrm{DM})$ ranged from $3.38 \mathrm{Mg}^{-1}$ in the zero-fert treatment to $12.27 \mathrm{Mg} \mathrm{ha}^{-1}$ in the NPK treatment. In comparison with the zero-fert treatment, grain and straw yields were significantly higher in all fertilized treatments in 2015 and in treatments No. 2, 3, and 4 in 2018. Winter wheat yields were lowest in the 2.0 Mg MBM treatment. In 2015, grain 
yield was over $1.5 \mathrm{Mg} \mathrm{ha}^{-1}$ lower in this treatment than in the NPK treatment (significant difference). Salomonsson et al. [26] found no significant difference in the grain yield of spring wheat between MBM and urea treatments, which were significantly more effective than slurry manure. In the present experiment, the greatest difference in winter wheat yields was observed between the years of study-average grain yield was around two-fold higher in 2015 than in 2018 (Table 2). The growing season of 2017/18 was characterized by highly unfavorable weather conditions, starting with excessive precipitation in September (2.6-fold higher than in 2014/15), which hampered sowing, through sub-zero temperatures in February and March accompanied by considerable precipitation deficit, ending with too wet July, which hindered harvest. In a study by Nogalska [14], the optimal MBM dose for spring barley was $1.5 \mathrm{Mg} \mathrm{ha}^{-1}$, i.e., approximately $120 \mathrm{~kg} \mathrm{~N}$ and $70 \mathrm{~kg} \mathrm{P} \mathrm{ha}^{-1}$ year $^{-1}$. This dose was sufficient to produce over $5.0 \mathrm{Mg} \mathrm{ha}^{-1}$ of grain. An increase in MBM dose from 1.5 to $2.5 \mathrm{Mg} \mathrm{ha}^{-1}$ did not contribute to a significant increase in crop yields (triticale, oilseed rape, wheat, and maize); therefore, the MBM dose of $1.5 \mathrm{Mg} \mathrm{ha}^{-1}$ was optimal in soils with a moderate abundance of P [12]. Pot experiments conducted by Jeng et al. [3] revealed that mineral $\mathrm{N}$ fertilizer combined with MBM exerted the strongest yield-forming effect on spring barley. Several field trials involving cereals were conducted in Finland to determine the fertilizing effect of MBM-N as compared with mineral fertilizers. It was found that the grain yields of barley and oats supplied with MBM and mineral fertilizer did not differ significantly [7].

Oilseed rape was grown in the growing seasons of 2015/16 and 2016/17, and seed and straw yields ranged from 1.63 to $3.29 \mathrm{Mg} \mathrm{ha}^{-1}$ and from 2.04 to $4.01 \mathrm{Mg} \mathrm{ha}^{-1}$, respectively (Table 3). The yields of winter oilseed rape were significantly higher in all fertilized treatments than in the zero-fert treatment. The highest seed yield was noted in the NPK treatment, and it was significantly higher than in the $2.0 \mathrm{Mg}$ MBM treatment $(2015 / 16)$ and in the remaining fertilized treatments (2016/17). In 2016, straw yield was highest in the treatment where MBM was supplemented with mineral $\mathrm{N}$ at $50 \%$ of the total $\mathrm{N}$ rate, and the difference was significant relative to the treatment where only MBM was used. In the growing season of 2016/17, no significant differences in straw yield were noted between fertilized treatments. In both growing seasons, weather conditions (Table 2) were not conducive to the growth and development of winter oilseed rape; therefore, the yields were relatively low but stable (Table 3). Previous research shows that the seed yield of winter oilseed rape can be higher (3.7-4.2 $\mathrm{Mg} \mathrm{ha}^{-1}$ ) when MBM is applied at 1.0-2.5 Mg ha-1 without supplemental mineral N [12]. Stępień and Wojtkowiak [27] noted even higher seed yields of winter oilseed rape (4.6-5.3 $\mathrm{Mg} \mathrm{ha}^{-1}$ ) at similar MBM doses. However, oilseed rape yields are largely determined by factors other than fertilization such as cultivar and agronomic and environmental conditions [28,29]. According to Weymann et al. [30], the seed yield of oilseed rape is affected by weather conditions during the growing season in around $40 \%$. In the current study, adverse weather conditions (Table 2) were mostly responsible for the relatively low average seed yield of winter oilseed rape, which reached 2.7 $\mathrm{Mg} \mathrm{ha}^{-1}$ in fertilized treatments (Table 3).

It can be concluded that the yields of the tested crops were higher in MBM treatments than in the zero-fert treatment. The yield of silage maize supplied with MBM was comparable with that of plants fertilized with NPK. The yields of winter wheat and winter oilseed rape were highest in the NPK treatment and lowest in the $2.0 \mathrm{Mg} \mathrm{ha}^{-1} \mathrm{MBM}$ treatment. The addition of $25 \%$ and $50 \%$ of mineral $\mathrm{N}$ to MBM had no influence on the yields of the tested crops.

\subsection{Nitrogen Content of Plants}

In most cases, the $\mathrm{N}$ content of the aboveground biomass of the tested crops was modified by fertilization (Table 4). In the first year of the experiment, maize herbage had the highest $\mathrm{N}$ content in the NPK treatment $\left(12.38 \mathrm{~g} \mathrm{~kg}^{-1} \mathrm{DM}\right)$ and in the $1.0 \mathrm{Mg} \mathrm{MBM}+\mathrm{N}_{79}$ treatment $\left(12.11 \mathrm{~g} \mathrm{~kg}^{-1} \mathrm{DM}\right)$, and the differences were significant relative to the zero-fert treatment. In the last year of the experiment, the $\mathrm{N}$ content of maize herbage was highest 
in the NPK treatment $\left(11.19 \mathrm{~g} \mathrm{~kg}^{-1} \mathrm{DM}\right)$ and in the $2.0 \mathrm{Mg}$ MBM treatment $\left(9.89 \mathrm{~g} \mathrm{~kg}^{-1}\right.$ $\mathrm{DM})$. In both years of maize cultivation, no significant differences in the $\mathrm{N}$ content of herbage were found between treatments No. 3,4, and 5. This indicates that different rates of supplemental mineral $\mathrm{N}$ added to MBM or its absence (treatment No. 5) had no significant effect on $\mathrm{N}$ accumulation in maize biomass. In an experiment conducted by Nogalska et al. [12], the protein yield of silage maize was significantly affected by different MBM doses, but it did not increase linearly in response to increasing MBM doses. The total $\mathrm{N}$ rate was identical in the NPK treatment and in $2 \mathrm{Mg} \mathrm{ha}^{-1} \mathrm{MBM}$, and the protein yield of maize was significantly higher in response to MBM than NPK fertilization. Irrespective of weather conditions during the study, mineral fertilization (NPK) and the application of MBM at $1.0-3.0 \mathrm{Mg} \mathrm{ha}^{-1}$ contributed to an increase in protein concentration in maize grain [15]. However, only the highest MBM dose ( $3.0 \mathrm{Mg}^{-1}$, i.e., over $\left.230 \mathrm{~kg} \mathrm{~N} \mathrm{ha}^{-1}\right)$ caused a significant increase in the protein content of maize grain, relative to the remaining fertilized treatments.

Table 4. The effect of increasing MBM doses on the nitrogen content $\left(\mathrm{g} \mathrm{kg}^{-1} \mathrm{DM}\right)$ of crops in rotation.

\begin{tabular}{|c|c|c|c|c|c|c|c|c|c|c|}
\hline \multirow[t]{2}{*}{ Treatments } & \multirow{2}{*}{$\begin{array}{c}2014 \\
\text { Maize } \\
\text { Herbage }\end{array}$} & \multicolumn{2}{|c|}{$\begin{array}{c}2014 / 15 \\
\text { Winter Wheat }\end{array}$} & \multicolumn{2}{|c|}{$\begin{array}{c}\text { 2015/16 } \\
\text { Winter Oilseed } \\
\text { Rape }\end{array}$} & \multicolumn{2}{|c|}{$\begin{array}{c}2016 / 17 \\
\text { Winter Oilseed } \\
\text { Rape }\end{array}$} & \multicolumn{2}{|c|}{$\begin{array}{c}2017 / 18 \\
\text { Winter Wheat }\end{array}$} & \multirow{2}{*}{$\begin{array}{c}2019 \\
\text { Maize } \\
\text { Herbage }\end{array}$} \\
\hline & & Grain & Straw & Seeds & Straw & Seeds & Straw & Grain & Straw & \\
\hline 1. Zero-fert & $10.10^{\mathrm{a}}$ & 14.76 & $4.47^{\mathrm{a}}$ & $28.38^{a}$ & $4.01^{\mathrm{a}}$ & 28.29 & 5.61 & $17.56^{\mathrm{a}}$ & 4.15 & $7.43^{\mathrm{a}}$ \\
\hline 2. Inorganic NPK * & $12.38^{b}$ & 16.00 & $5.73^{a b}$ & $33.01^{\mathrm{b}}$ & $6.88^{c}$ & 30.21 & 6.07 & $21.24^{b}$ & 4.55 & $11.19^{c}$ \\
\hline 3. $1.0 \mathrm{Mg} \mathrm{MBM}+\mathrm{N}_{79} * *$ & $12.11^{b}$ & 14.40 & $6.77^{\mathrm{b}}$ & $31.36^{\mathrm{ab}}$ & $5.98^{b c}$ & 29.14 & 5.76 & $21.42^{b}$ & 4.34 & $9.08^{a b}$ \\
\hline 4. $1.5 \mathrm{Mg} \mathrm{MBM}+\mathrm{N}_{40}{ }^{* * *}$ & $11.22^{\mathrm{ab}}$ & 14.03 & $6.45^{\mathrm{ab}}$ & $28.18^{\mathrm{a}}$ & $4.40^{\mathrm{ab}}$ & 28.74 & 5.90 & $21.06^{b}$ & 4.40 & $8.99 \mathrm{ab}$ \\
\hline 5. $2.0 \mathrm{Mg} \mathrm{MBM} * * * *$ & $11.57^{\mathrm{ab}}$ & 15.75 & $6.14^{\mathrm{ab}}$ & $29.93^{a b}$ & $6.08^{b c}$ & 29.61 & 6.75 & $21.77^{b}$ & 4.66 & $9.89^{b c}$ \\
\hline Mean & 11.48 & 14.99 & 5.91 & 30.17 & 5.47 & 29.20 & 6.02 & 20.61 & 4.42 & 9.32 \\
\hline
\end{tabular}

* Inorganic NPK-mineral fertilization; ${ }^{* *} \mathrm{MBM}+\mathrm{N}_{79}$-meat and bone meal with mineral nitrogen $\left(79 \mathrm{~kg} \mathrm{~N}\right.$ ha $\left.{ }^{-1}\right)$ fertilizers; ${ }^{* * *} \mathrm{MBM}+$ $\mathrm{N}_{40}$-meat and bone meal with mineral nitrogen $\left(40 \mathrm{~kg} \mathrm{~N} \mathrm{ha}^{-1}\right)$ fertilizers; ${ }^{* * * *} \mathrm{MBM}-$ meat and bone meal fertilizer. Every year in the two, three, four, and five treatments applied mineral fertilization with potassium, the same dose of $145 \mathrm{~kg} \mathrm{~K} \mathrm{ha}^{-1}$. a, b, c, ab, bc-significant differences between means for fertilization (in columns), according to Tukey's test $(p<0.05)$. The absence of superscript letters (in columns) indicates no significant differences between means.

Winter wheat grain was more abundant in $\mathrm{N}$ in 2018 than in 2015; in the growing season of 2017/18, the average $\mathrm{N}$ content of grain was $21.4 \mathrm{~g} \mathrm{~kg}^{-1} \mathrm{DM}$ in fertilized treatments and $17.56 \mathrm{~g} \mathrm{~kg}^{-1} \mathrm{DM}$ in the zero-fert treatment, and the differences were significant (Table 4). In 2014/15, winter wheat straw was abundant in N, particularly in the 1.0 $\mathrm{Mg} \mathrm{MBM}+\mathrm{N}_{79}$ treatment $\left(6.77 \mathrm{~g} \mathrm{~kg}^{-1} \mathrm{DM}\right)$, and the difference was significant relative to the zero-fert treatment $\left(4.47 \mathrm{~g} \mathrm{~kg}^{-1} \mathrm{DM}\right)$. This suggests that $\mathrm{N}$ was not completely translocated to grain, which contained $14.99 \mathrm{~g} \mathrm{~N} \mathrm{~kg}^{-1} \mathrm{DM}$ on average. Salomonsson et al. [31] reported that the protein content of grain in winter wheat fertilized with MBM and urea was comparable. In general, when MBM is applied to cereals in spring, the relative $\mathrm{N}$ efficiency of MBM is at least $80 \%$ or higher compared to mineral fertilizer [3]. Stępień and Wojtkowiak [32] demonstrated that the protein content of spring wheat grain increased significantly in response to NPK fertilization, manure, and MBM, but protein composition was most desirable after the application of $1.5 \mathrm{Mg} \mathrm{ha}^{-1} \mathrm{MBM}$.

The $\mathrm{N}$ content of winter oilseed rape seeds and straw were similar in both years of cultivation, and significant differences between treatments were observed in the growing season of 2015/16 (Table 4). The seeds of winter oilseed rape fertilized with NPK accumulated significantly more $\mathrm{N}$ (by over $14 \%$ on average, $33.01 \mathrm{~g} \mathrm{~kg}^{-1} \mathrm{DM}$ ), compared with the $1.5 \mathrm{Mg} \mathrm{MBM}+\mathrm{N}_{40}$ treatment $\left(28.18 \mathrm{~g} \mathrm{~N} \mathrm{~kg}^{-1} \mathrm{DM}\right)$ and the zero-fert treatment $\left(28.38 \mathrm{~g} \mathrm{~N} \mathrm{~kg}^{-1} \mathrm{DM}\right)$. It should be noted that seeds harvested in treatments No. 3 and 5 and the NPK treatment had comparable N content. Similar changes in N content were observed in the straw of winter oilseed rape. Stępień and Wojtkowiak [27] noted a gradual increase in the protein content of winter oilseed rape seeds and the grain of spring and winter wheat with increasing MBM doses. In earlier studies, MBM at doses lower 
than $1.5 \mathrm{Mg} \mathrm{ha}^{-1}$ (less than $120 \mathrm{~kg} \mathrm{~N} \mathrm{ha}^{-1}$ ) did not fully meet the $\mathrm{N}$ requirements of the analyzed crops [9-12,14,23].

\subsection{Nitrogen Uptake by Plants}

Nutrient uptake by plants is one of the key criteria for fertilizer evaluation, and it is determined based on the produced biomass and the content of the analyzed nutrients in biomass. Nitrogen uptake (on a DM basis, mean of two years) was highest in maize $\left(214 \mathrm{~kg} \mathrm{ha}^{-1}\right)$, followed by winter wheat $\left(130 \mathrm{~kg} \mathrm{ha}^{-1}\right)$, and it was lowest in winter oilseed rape $\left(99 \mathrm{~kg} \mathrm{ha}^{-1}\right)$ (Table 5).

Table 5. The effect of increasing MBM doses on nitrogen uptake ( $\left.\mathrm{kg} \mathrm{ha}^{-1} \mathrm{DM}\right)$ by crops in rotation.

\begin{tabular}{|c|c|c|c|c|c|c|}
\hline Treatments & $\begin{array}{c}2014 \\
\text { Maize } \\
\text { Herbage }\end{array}$ & $\begin{array}{l}\text { 2014/15 } \\
\text { Winter } \\
\text { Wheat }\end{array}$ & $\begin{array}{c}\text { 2015/16 } \\
\text { Winter Oilseed } \\
\text { Rape }\end{array}$ & $\begin{array}{c}2016 / 17 \\
\text { Winter Oilseed } \\
\text { Rape }\end{array}$ & $\begin{array}{l}\text { 2017/18 } \\
\text { Winter } \\
\text { Wheat }\end{array}$ & $\begin{array}{c}2019 \\
\text { Maize } \\
\text { Herbage }\end{array}$ \\
\hline 1. Zero-fert & $138.34^{\mathrm{a}}$ & $87.03^{a}$ & $54.73^{\mathrm{a}}$ & $57.53^{a}$ & $58.82^{\mathrm{a}}$ & $129.96^{\mathrm{a}}$ \\
\hline 2. Inorganic NPK* & $232.01^{b}$ & $201.27^{b}$ & $135.45^{\mathrm{d}}$ & $123.59^{c}$ & $115.10^{b}$ & $264.97^{b}$ \\
\hline 3. $1.0 \mathrm{Mg} \mathrm{MBM}+\mathrm{N}_{79}$ ** & $228.48^{b}$ & $182.69^{b}$ & $115.76^{c}$ & $108.77^{b c}$ & $110.03^{b}$ & $234.99^{b}$ \\
\hline 4. $1.5 \mathrm{Mg} \mathrm{MBM}+\mathrm{N}_{40}$ *** & $231.55^{b}$ & $168.58^{b}$ & $98.38^{b c}$ & $105.72 \mathrm{bc}$ & $99.70^{b}$ & $224.71^{b}$ \\
\hline 5. $2.0 \mathrm{Mg} \mathrm{MBM} * * * *$ & $221.71^{b}$ & $177.27^{b}$ & $95.06^{b}$ & $96.33^{\mathrm{b}}$ & $101.37^{\mathrm{b}}$ & $235.35^{b}$ \\
\hline Mean & 210.42 & 163.37 & 99.88 & 98.39 & 97.00 & 218.00 \\
\hline
\end{tabular}

* Inorganic NPK-mineral fertilization; ${ }^{* *} \mathrm{MBM}+\mathrm{N}_{79}$-meat and bone meal with mineral nitrogen $\left(79 \mathrm{~kg} \mathrm{~N}\right.$ ha $\left.{ }^{-1}\right)$ fertilizers; ${ }^{* * *} \mathrm{MBM}+$ $\mathrm{N}_{40}$ - meat and bone meal with mineral nitrogen $\left(40 \mathrm{~kg} \mathrm{~N} \mathrm{ha}^{-1}\right)$ fertilizers; **** $\mathrm{MBM}-$ meat and bone meal fertilizer. Every year in the two, three, four, and five treatments applied mineral fertilization with potassium, the same dose of $145 \mathrm{~kg} \mathrm{~K} \mathrm{ha}^{-1}$. a, b, c, d, bc-significant differences between means for fertilization (in columns), according to Tukey's test $(p<0.05)$.

Nitrogen uptake by all tested crops was significantly higher in fertilized treatments than in the zero-fert treatment. It should be stressed that $\mathrm{N}$ uptake by maize and winter wheat did not differ significantly between fertilized treatments, which indicates that different proportions of mineral $\mathrm{N}$ in the total $\mathrm{N}$ rate had no significant influence on $\mathrm{N}$ uptake by their biomass. A different trend was noted in winter oilseed rape where $\mathrm{N}$ uptake was highest in the NPK treatment and lowest in the treatment where only MBM was applied. The difference between these treatments was significant (approximately $26 \%$, mean of two years). According to Nogalska [6], winter oilseed rape does not utilize excessive $\mathrm{N}$ supplied by high MBM doses because it takes up considerably lower quantities of $\mathrm{N}$ than maize and winter wheat. In the present study, winter wheat was characterized by the greatest variation in $\mathrm{N}$ uptake between the years of cultivation, which exceeded $163 \mathrm{~kg} \mathrm{ha}^{-1}$ in the growing season of 2014/15 and reached only $97 \mathrm{~kg} \mathrm{ha}^{-1}$ in 2017/18 (1.7-fold decrease). This difference was due to fact that winter wheat yield was around two-fold lower on average in 2018 than in 2015. In experiments involving wheat, no significant differences in N uptake efficiency were found between MBM and urea, which in most cases were significantly more effective than slurry manure [26,31]. In spring barley, $\mathrm{N}$ uptake varied significantly across years of the experiment, and the noted differences resulted from higher yields and greater $\mathrm{N}$ abundance in plants [14]. In a study by Jeng et al. [3], an increase in the rate of $\mathrm{N}$ applied with MBM from 60 to $180 \mathrm{~kg}$ increased $\mathrm{N}$ uptake by spring barley 3.8 -fold. However, this value was significantly lower compared with similar rates of mineral N. Nogalska [6] and Nogalska et al. [11] reported that cereals fertilized with high MBM doses (above $2.0 \mathrm{Mg} \mathrm{ha}^{-1}$ ) accumulated significantly more $\mathrm{N}$ relative to the treatments fertilized with mineral $\mathrm{N}$. However, there is also evidence to show that the fertilizing effect of MBM is significantly lower than that of mineral fertilizers, yet reaching $81 \%$ in spring wheat [3]. Nevertheless, MBM can be considered a highly efficient organic fertilizer whose fertilizing effect accounts for at least $80 \%$ of the that exerted by mineral $\mathrm{N}$ fertilizers. Such a strong effect, compared with alternative organic fertilizers, may be due to the relatively fast mineralization of organic $N$ forms [33]. The latter can be partly attributed to the relatively low C:N ratio of MBM, which oscillates around 4 [3]. 


\subsection{Soil Mineral Nitrogen Content}

MBM combined with different rates of supplemental mineral $\mathrm{N}$ in a six-year crop rotation system had a significant influence on soil mineral $\mathrm{N}$ content $\left(\mathrm{N}-\mathrm{NO}_{3}, \mathrm{~N}-\mathrm{NH}_{4}\right.$, and their sum $-\mathrm{N}_{\text {min. }}$, which was significantly higher in all fertilized treatments than in the zero-fert treatment (Table 6).

Table 6. The effect of increasing MBM doses on the mineral nitrogen content $\left(\mathrm{mg} \mathrm{kg}^{-1} \mathrm{DM}\right)$ of soil, mean for 2014-2019.

\begin{tabular}{|c|c|c|c|c|}
\hline \multicolumn{2}{|c|}{ Treatment } & $\mathrm{N}-\mathrm{NO}_{3}$ & $\mathrm{~N}-\mathrm{NH}_{4}$ & $\mathbf{N}_{\min }$ \\
\hline \multicolumn{2}{|c|}{ 1. Zero-fert } & $2.31^{\mathrm{a}}$ & $3.94^{\mathrm{a}}$ & $6.25^{\mathrm{a}}$ \\
\hline \multicolumn{2}{|c|}{ 2. Inorganic NPK* } & $3.73^{d}$ & $4.80^{\mathrm{b}}$ & $8.53^{c}$ \\
\hline \multicolumn{2}{|c|}{ 3. $1.0 \mathrm{Mg} \mathrm{MBM}+\mathrm{N}_{79}$ ** } & $3.36^{\mathrm{cd}}$ & $4.65^{b}$ & $8.01 \mathrm{bc}$ \\
\hline \multicolumn{2}{|c|}{ 4. $1.5 \mathrm{Mg} \mathrm{MBM}+\mathrm{N}_{40} * * *$} & $2.85^{b}$ & $4.77^{\mathrm{b}}$ & $7.62^{b}$ \\
\hline \multicolumn{2}{|c|}{ 5. $2.0 \mathrm{Mg} \mathrm{MBM}^{* * * *}$} & $3.15 \mathrm{bc}$ & $4.78^{b}$ & $7.93 \mathrm{bc}$ \\
\hline \multirow{6}{*}{ Annual mean } & 2014 & $2.53^{\mathrm{B}}$ & $4.93^{\mathrm{C}}$ & $7.46^{\mathrm{B}}$ \\
\hline & 2015 & $1.49^{\mathrm{A}}$ & $3.55^{\mathrm{A}}$ & $5.04^{\mathrm{A}}$ \\
\hline & 2016 & $2.82^{\mathrm{B}}$ & $4.04^{\mathrm{A}}$ & $6.87^{\mathrm{B}}$ \\
\hline & 2017 & $6.49^{\mathrm{D}}$ & $6.00^{\mathrm{D}}$ & $12.50^{\mathrm{D}}$ \\
\hline & 2018 & $3.81^{\mathrm{C}}$ & $4.81^{\mathrm{BC}}$ & $8.62^{C}$ \\
\hline & 2019 & $1.33^{\mathrm{A}}$ & $4.21 \mathrm{AB}$ & $5.53^{\mathrm{A}}$ \\
\hline
\end{tabular}

* Inorganic NPK-mineral fertilization; ${ }^{* *} \mathrm{MBM}+\mathrm{N}_{79}$-meat and bone meal with mineral nitrogen $\left(79 \mathrm{~kg} \mathrm{~N}\right.$ ha $\left.^{-1}\right)$ fertilizers; ${ }^{* * *} \mathrm{MBM}+\mathrm{N}_{40}$-meat and bone meal with mineral nitrogen $\left(40 \mathrm{~kg} \mathrm{~N}\right.$ ha $\left.{ }^{-1}\right)$ fertilizers; ${ }^{* * *}$ MBM-meat and bone meal fertilizer. Every year in the two, three, four, and five treatments applied mineral fertilization with potassium, the same dose of $145 \mathrm{~kg} \mathrm{~K} \mathrm{ha}^{-1}$. a, b, c, d, bc, cd-significant differences between means for fertilization (in columns), A, B, C, D, AB, BC-significant differences between means for the years 2014-2019 (in columns), according to Tukey's test $(p<0.05)$. Interaction between fertilization and year $((\mathrm{f} \times \mathrm{y})$; $\mathrm{s}-$ significant; ns-not significant.

In the NPK treatment, where urea $(46 \% \mathrm{~N})$ and ammonium nitrate $(34 \% \mathrm{~N})$ were applied, mineral $\mathrm{N}$ content increased significantly (by $27 \%$ ) relative to the zero-fert treatment and by $11 \%$ relative to treatment No. 4 . The highest levels of $\mathrm{N}-\mathrm{NO}_{3}$ were noted in the NPK treatment and in the $1.0 \mathrm{Mg} \mathrm{MBM}+\mathrm{N}_{79}$ treatment (3.73 and $3.36 \mathrm{mg} \mathrm{kg}^{-1}$ soil, respectively). The content of ${\mathrm{N}-\mathrm{NO}_{3}}_{3}$ in soil was lowest $\left(2.85 \mathrm{mg} \mathrm{kg}^{-1}\right)$ in the $1.5 \mathrm{Mg}$ $\mathrm{MBM}+\mathrm{N}_{40}$ treatment, and it did not differ significantly only from the value noted in the 2.0 Mg MBM treatment. No significant changes in the content of ammonium $\mathrm{N}$ in soil were observed in fertilized treatments. It should be stressed that the content of $\mathrm{N}-\mathrm{NO}_{3}$ and $\mathrm{N}-\mathrm{NH}_{4}$ is soil was comparable in the treatments where MBM was applied alone and in combination with different rates of mineral $\mathrm{N}$. The environmental impact of MBM is a very important consideration. The analyzed soil had a higher content of ammonium $\mathrm{N}$ than nitrate $\mathrm{N}$, which is consistent with previous findings [6]. Soil samples were collected at the end of the growing season (July-September), when the process of $\mathrm{N}^{-\mathrm{NO}_{3}-}$ leaching is intensified. This suggests that MBM poses no threat to the soil environment because $\mathrm{N}-\mathrm{NH}_{4} 4^{+}$is relatively effectively sorbed to the sorption complex. In a laboratory experiment performed by Bohacz and Korniłłowicz-Kowalska [34], soil contained greater quantities of nitrate $\mathrm{N}$ than ammonium $\mathrm{N}$ after the application of acidic and limed keratin-bark and keratin-bark-straw composts of chicken feathers. Stẹpień and Wojtkowiak [27] applied MBM every year at 2.0 and $2.5 \mathrm{Mg} \mathrm{ha}^{-1}$ and found that the content of mineral $\mathrm{N}$ increased 2.33- and 2.56-fold in comparison with unfertilized soil. Each additional 0.5 Mg MBM above $1.0 \mathrm{Mg} \mathrm{ha}^{-1}$ increased soil mineral $\mathrm{N}$ content by $4 \mathrm{mg}$. The highest rate of $\mathrm{N}^{-\mathrm{NO}_{3}}$ release was observed when MBM was applied at 2.0 and $2.5 \mathrm{Mg} \mathrm{ha}^{-1}$ in all years of the study, whereas the rate of $\mathrm{N}_{-} \mathrm{NH}_{4^{+}}$release was highest in the first year of the study. Jeng and Vagstadt [5] conducted a laboratory experiment to estimate the $\mathrm{N}$ and $\mathrm{P}$ leaching effect of MBM. MBM was applied at different $\mathrm{N}$ levels $\left(60,120\right.$, and $\left.180 \mathrm{~kg} \mathrm{ha}^{-1}\right)$ together with mineral fertilizer to soil columns (devoid of vegetation cover), and the amounts of leached nutrients were analyzed. Nutrient leaching from MBM-treated columns was lower than 
from those treated with mineral $\mathrm{N}$ fertilizer, and $\mathrm{N}-\mathrm{NO}_{3}$ leaching losses accounted for only $13-17 \%$ of the applied $\mathrm{N}$, compared with $31 \%$ of mineral fertilizer. It should be noted that nutrient losses could be significantly lower in the presence of vegetation cover.

Soil mineral $\mathrm{N}$ content varied significantly throughout the experiment, and it was largely determined by $\mathrm{N}$ uptake by plants (Table 6). The content of mineral $\mathrm{N}$ in soil was highest $\left(12.50 \mathrm{mg} \mathrm{kg}^{-1}\right)$ in the fourth year of the study, and it was significantly (1.9-fold) higher than in the remaining years due to low $\mathrm{N}$ uptake (approximately $99 \mathrm{~kg} \mathrm{ha}^{-1}$ year $^{-1}$ ) by winter oilseed rape grown in the third and fourth year. The second-highest mineral $\mathrm{N}$ content of soil was noted in the fifth year of the experiment $\left(8.62 \mathrm{mg} \mathrm{kg}^{-1}\right)$, after the harvest of winter wheat. In this year, winter wheat was characterized by a relatively low yield and the lowest $\mathrm{N}$ uptake $\left(97 \mathrm{~kg} \mathrm{ha}^{-1}\right)$ of all tested crops. The content of mineral $\mathrm{N}$, in particular nitrate $\mathrm{N}\left(1.78 \mathrm{mg} \mathrm{kg}^{-1}\right.$ on average) in soil, was lowest after both maize harvests and after winter wheat harvest in the second year of the study. Maize and winter wheat had high $\mathrm{N}$ requirements, and they took up 214 and $163 \mathrm{~kg} \mathrm{~N}^{-1}$ on average. The relatively low content of $\mathrm{N}_{-} \mathrm{NO}_{3}$ - in soil points to a low risk of environmental pollution, but it may also suggest that the amount of plant-available $\mathrm{N}$ was inadequate. However, soil mineral $\mathrm{N}$ balance in the above treatments was positive (approximately $20 \mathrm{~kg} \mathrm{ha}^{-1}$ ). In another study, soil mineral $\mathrm{N}$ content was relatively high after the harvest of maize, which took up $207.82 \mathrm{~kg} \mathrm{~N} \cdot \mathrm{ha}^{-1}$ on average, leaving considerable amounts of residues [6]. The mineralization of organic $\mathrm{N}$ compounds in soil leads to the release of mineral $\mathrm{N}$ whose availability is affected by its form, weather conditions, and crop species [35]. In the work of Nogalska [6], soil abundance in mineral $\mathrm{N}$ was determined by MBM doses, followed by crop species and weather conditions. The nitrate $\mathrm{N}$ content of soil was lowest after winter triticale harvest in the first year of the study, due to uneven distribution of precipitation and short-term mineralization of organic N from MBM. Under laboratory conditions, $65 \%$ of organic $\mathrm{N}$ from MBM became available to plants after 35-50 days of mineralization [36]. Chaves et al. [4] also found that organic N from five MBMs was mineralized in 43-64\% during 20-week aerobic incubation in differently textured soils. Mineralization takes much longer in soils fertilized with keratin-bark-straw composts of chicken feathers [34].

\subsection{Soil Mineral Nitrogen Balance}

Total $\mathrm{N}$ uptake by all tested crops during the six-year field experiment ranged from $526 \mathrm{~kg}$ in the zero-fert treatment to $1072 \mathrm{~kg}$ in the NPK treatment (Table 7).

Table 7. Calculated cumulative nitrogen balance for the years 2014-2019.

\begin{tabular}{|c|c|c|c|c|}
\hline Treatment & $\begin{array}{c}\text { Dose } \\
\left(\mathrm{kg} \mathrm{ha}^{-1}\right)\end{array}$ & $\begin{array}{c}\text { Uptake } \\
\left(\mathrm{kg} \mathrm{ha}^{-1}\right)\end{array}$ & $\begin{array}{l}\text { Balance } \\
\left(\mathrm{kg} \mathrm{ha}^{-1}\right)\end{array}$ & $\begin{array}{c}\text { Utilization } \\
(\%)\end{array}$ \\
\hline 1. Zero-fert & 0 & 526.4 & -526.4 & \\
\hline 2. Inorganic NPK * & $948(0+948)$ & 1072.4 & -124.4 & 57.6 \\
\hline 3. $1.0 \mathrm{Mg} \mathrm{MBM}+\mathrm{N}_{79} * *$ & $948(474+474)$ & 980.7 & -32.7 & 47.9 \\
\hline 4. $1.5 \mathrm{Mg} \mathrm{MBM}+\mathrm{N}_{40} * * *$ & $948(240+708)$ & 928.6 & 19.4 & 42.4 \\
\hline 5. $2.0 \mathrm{Mg} \mathrm{MBM}^{* * * *}$ & $948(948+0)$ & 927.1 & 20.9 & 42.3 \\
\hline Mean & 948 & 887.1 & -128.7 & 47.6 \\
\hline
\end{tabular}

* Inorganic NPK-mineral fertilization; ${ }^{* *} \mathrm{MBM}+\mathrm{N}_{79}$ - meat and bone meal with mineral nitrogen $\left(79 \mathrm{~kg} \mathrm{~N} \mathrm{ha}^{-1}\right)$ fertilizers; ${ }^{* * *} \mathrm{MBM}+\mathrm{N}_{40}$-meat and bone meal with mineral nitrogen $\left(40 \mathrm{~kg} \mathrm{~N}^{-1}\right)$ fertilizers; ${ }^{* * * *} \mathrm{MBM}-\mathrm{meat}$ and bone meal fertilizer. Every year in the two, three, four, and five treatments applied mineral fertilization with potassium, the same dose of $145 \mathrm{~kg} \mathrm{~K} \mathrm{ha}^{-1}$.

The highest $\mathrm{N}$ uptake from soil supplied with mineral fertilizers resulted from higher yields of winter wheat and winter oilseed rape, and $\mathrm{N}$ concentrations in maize herbage, winter oilseed rape seeds, and winter wheat grain in the second year of the study. An analysis of $\mathrm{N}$ balance revealed that the annual $\mathrm{N}$ rate of $158 \mathrm{~kg} \mathrm{ha}^{-1}$ applied to each crop for six years (948 $\mathrm{kg} \mathrm{N} \mathrm{ha}^{-1}$ in total) was insufficient to meet the $\mathrm{N}$ requirements of plants in two treatments (No. 2 and 3). The greatest $\mathrm{N}$ deficiency was noted in the NPK treatment $\left(-124 \mathrm{~kg} \mathrm{ha}^{-1}\right)$ and in the $1.0 \mathrm{Mg} \mathrm{MBM}+\mathrm{N}_{79}$ treatment $\left(-33 \mathrm{~kg} \mathrm{~N} \mathrm{ha}^{-1}\right)$. 
In these treatments, $\mathrm{N}$ from mineral fertilizers (urea and ammonium nitrate) was most effectively utilized by plants (in 58\% and $48 \%$, respectively). Interestingly, $\mathrm{N}$ utilization by plants was identical (over $42 \%$ ) in the $1.5 \mathrm{Mg} \mathrm{MBM}+\mathrm{N}_{40}$ and $2.0 \mathrm{Mg} \mathrm{MBM}$ treatments, and $\mathrm{N}$ balance was positive only in these treatments ( $20 \mathrm{~kg} \mathrm{ha}^{-1}$ over six years on average). In previous studies, $\mathrm{N}$ balance in treatments with mineral fertilizers and MBM was usually negative, and $\mathrm{N}$ utilization ranged from $45 \%$ to $74 \%$ depending on MBM dose $[9,23]$.

\section{Conclusions}

Under sustainable nutrient and organic matter management, MBM as a by-product of the meat industry is an important pathway for $\mathrm{N}$ and $\mathrm{P}$ recycling in line with the European Green Deal that promotes lower energy use in mineral fertilizer production, environmental protection, and circular economy. The use of MBM for agricultural purposes prevents its long-term storage and expensive disposal by incineration. In Poland, MBM is still classified as a soil amendment, not organic fertilizer. The present findings indicate that MBM can be an effective fertilizer in maize production and, to a lesser degree, in winter wheat and winter oilseed rape cultivation. The yields of the tested crops were higher in MBM treatments than in the zero-fert treatment. The yield of silage maize supplied with MBM was comparable with that of plants fertilized with NPK. The yields of winter wheat and winter oilseed rape were generally highest in the NPK treatment, and lowest in the $2.0 \mathrm{Mg} \mathrm{ha}^{-1} \mathrm{MBM}$ treatment. The addition of $25 \%$ and $50 \%$ of mineral $\mathrm{N}$ to MBM had no influence on the yields of the tested crops or the $\mathrm{N}$ content and uptake by plants. The $\mathrm{N}$ content of plants fertilized with MBM was satisfactory (higher than in the zero-fert treatment), and considerable differences were found between years of the study within crop species. Changes in soil mineral $\mathrm{N}$ content were affected by $\mathrm{N}$ uptake by plants rather than the proportion of mineral $\mathrm{N}$ in the total $\mathrm{N}$ rate. Soil mineral $\mathrm{N}$ content was highest in the NPK treatment, and significant differences were found relative to the zero-fert treatment and the $1.5 \mathrm{Mg} \mathrm{MBM}+\mathrm{N}_{40}$ treatment. Soil mineral $\mathrm{N}$ content was also highest after the harvest of crops that had taken up the smallest quantities of $\mathrm{N}$. In the six-year crop rotation system, the annual $\mathrm{N}$ rate of $158 \mathrm{~kg} \mathrm{ha}^{-1}\left(948 \mathrm{~kg} \mathrm{~N} \mathrm{ha}^{-1}\right.$ in total) was insufficient to meet the $\mathrm{N}$ requirements of plants in two treatments. A negative $\mathrm{N}$ balance was noted in the NPK treatment $\left(-124 \mathrm{~kg} \mathrm{ha}^{-1}\right)$ and in the $1.0 \mathrm{Mg} \mathrm{MBM}+\mathrm{N}_{79}$ treatment $\left(-33 \mathrm{~kg} \mathrm{~N} \mathrm{ha}^{-1}\right)$, where $\mathrm{N}$ utilization by plants was highest. Nitrogen utilization was identical in the $1.5 \mathrm{Mg}$ $\mathrm{MBM}+\mathrm{N}_{40}$ and $2.0 \mathrm{Mg} \mathrm{MBM}$ treatments. A better understanding of the factors influencing $\mathrm{N}$ uptake and utilization by plants can contribute to establishing the optimal fertilizer rate, thus reducing the amount of $\mathrm{N}$ that remains in the soil environment after harvest.

Author Contributions: Conceptualization, A.N. and A.Z.; methodology, A.N. and A.Z.; chemical analyses, A.Z.; data analysis, A.N. and A.Z.; investigation, A.N. and A.Z.; resources, A.N. and A.Z.; data curation, A.N. and A.Z.; writing, A.Z.; writing-review and editing, A.N.; visualization, A.Z.; supervision, A.N.; funding acquisition, A.N. All authors have read and agreed to the published version of the manuscript.

Funding: This research was supported by the Ministry of Education and Science as part of statutory activities (No. 30.610.003-110). The project was financially supported by the Minister of Education and Science under the program entitled "Regional Initiative of Excellence" for the years 2019-2022, Project No. 010/RID/2018/19, amount of founding 12.000.000 PLN.

Institutional Review Board Statement: Not applicable.

Informed Consent Statement: Not applicable.

Data Availability Statement: Not applicable.

Conflicts of Interest: The authors declare no conflict of interest.

\section{References}

1. Jeng, A.S.; Haraldsen, T.K.; Grønlund, A.; Pedersen, P.A. Meat and bone meal as nitrogen and phosphorus fertilizer to cereals and ryegrass. Nutr. Cycl. Agroecosyst. 2006, 76, 183-191. [CrossRef] 
2. Brod, E.; Øgaard, A.F.; Krogstad, T.; Haraldsen, T.K.; Frossard, E.; Oberson, A. Drivers of phosphorus uptake by barley following secondary resource application. Front. Nutr. 2016, 3, 12. [CrossRef] [PubMed]

3. Jeng, A.S.; Haraldsen, T.K.; Vagstadt, N.; Grønlund, N. Meat and bone meal as nitrogen fertilizer to cereals in Norway. Agric. Food Sci. 2004, 13, 268-275. [CrossRef]

4. Chaves, C.; Canet, R.; Albiach, R.; Marin, J.; Pomares, F. Meat and bone meal: Fertilizing value and rates of nitrogen mineralization. Nutr. Carbon Cycl. Sustain. Plant. Soil Syst. 2005, 1, 177-180.

5. Jeng, A.S.; Vagstadt, N. Potential nitrogen and phosphorus leaching from soils fertilized with meat and bone meal. Acta Agric. Scand. B Soil Plant. Sci. 2009, 59, 238-245. [CrossRef]

6. Nogalska, A. Changes in the soil nitrogen content caused by direct and residual effect of meat and bone meal. J. Elem. 2013, 18, 659-671. [CrossRef]

7. Chen, L.; Kivela, J.; Helenius, J.; Kangas, A. Meat bone meal as fertiliser for barley and oat. Agric. Food Sci. 2011, 20, 235-244. [CrossRef]

8. Brod, E.; Haraldsen, T.K.; Breland, T.A. Fertilization effects of organic waste resources and bottom wood ash: Results from a pot experiment. Agric. Food Sci. 2012, 21, 332-347. [CrossRef]

9. Nogalska, A.; Czapla, J.; Nogalski, Z.; Skwierawska, M.; Kaszuba, M. The effect of increasing doses of meat and bone meal (MBM) on maize (Zea mays L.) grown for grain. Agric. Food Sci. 2012, 21, 325-331. [CrossRef]

10. Nogalska, A.; Zalewska, M. The effect of meat and bone meal (MBM) on phosphorus concentrations in soil and crop plants. Plant Soil Environ. 2013, 59, 575-580. [CrossRef]

11. Nogalska, A.; Skwierawska, M.; Nogalski, Z.; Kaszuba, M. The effect of increasing doses of meat and bone meal (MBM) applied every second year on maize grown for grain. Chil. J. Agric. Res. 2013, 73, 430-434. [CrossRef]

12. Nogalska, A.; Chen, L.; Sienkiewicz, S.; Nogalski, Z. Meat and bone meal as nitrogen and phosphorus supplier to cereals and oilseed rape. Agric. Food Sci. 2014, 23, 19-27. [CrossRef]

13. Kivela, J.; Chen, L.; Muurinen, S.; Kivijarvi, P.; Hintikainen, V.; Helenius, J. Effects of meat bone meal as fertilizer on yield and quality of sugar beet and carrot. Agric. Food Sci. 2015, 24, 68-83. [CrossRef]

14. Nogalska, A. Meat and bone meal as fertilizer for spring barley. Plant Soil Environ. 2016, 62, 373-378. [CrossRef]

15. Stępień, A.; Wojtkowiak, K.; Kolankowska, E. Use of meat industry waste in the form of meat-and-bone meal fertilising maize (Zea mays L.) for grain. Sustainability 2021, 13, 2857. [CrossRef]

16. Silvasy, T.; Ahmad, A.A.; Wang, K.-H.; Radovich, T.J.K. Rate and timing of meat and bone meal applications influence growth, yield, and soil water nitrate concentrations in sweet corn production. Agronomy 2021, 11, 1945. [CrossRef]

17. Zhou, M.H.; Zhu, B.; Bruggemann, N.; Dannenmann, M.; Wang, Y.Q.; Butterbach-Bahl, K. Sustaining crop productivity while reducing environmental nitrogen losses in the subtropical wheat-maize cropping systems: A comprehensive case study of nitrogen cycling and balance. Agric. Ecosyst. Environ. 2016, 231, 1-14. [CrossRef]

18. Nogalska, A.; Załuszniewska, A. The effect of meat and bone meal applied without or with mineral nitrogen on macronutrient content and uptake by winter oilseed rape. J. Elem. 2020, 25, 905-915. [CrossRef]

19. Załuszniewska, A.; Nogalska, A. The effect of meat and bone meal (MBM) on the seed yield and quality of winter oilseed rape. Agronomy 2020, 10, 1952. [CrossRef]

20. IUSS Working Group WRB. World Reference Base for Soil Resources 2014. In International Soil Classification System for Naming Soils and Creating Legends for Soil Maps; Update 2015; World Soil Resources Report No. 106; FAO: Rome, Italy, 2015.

21. STATSOFT, INC. Statistica (Data Analysis Software System), Version 12. 2012. Available online: www.statsoft.com (accessed on 28 July 2021).

22. Ylivainio, K.; Uusitalo, R.; Turtola, E. Meat and bone meal and fox manure as P source for ryegrass (Lolium multiflorum) grown on a limed soil. Nutr. Cycl. Agroecosyst. 2008, 81, 267-278. [CrossRef]

23. Nogalska, A.; Krzebietke, S.J.; Zalewska, M.; Nogalski, Z. The effect of meat and bone meal (MBM) on the nitrogen and phosphorus content and pH of soil. Agric. Food Sci. 2017, 26, 181-187. [CrossRef]

24. Nogalska, A.; Skwierawska, M.; Załuszniewska, A. The effect of meat and one meal (MBM) and Bacillus subtilis on the content of nitrogen and phosphorus in soil and white mustard biomass. Agric. Food Sci. 2018, 27, 275-282. [CrossRef]

25. Venegas, F. Meat and bone meal as phosphorus source to production of maize (Zea mays L.). Ens. Cienc. Cienc. Biol. Agrar. Saude 2009, 23, 63-76.

26. Salomonsson, L.; Jonsson, A.; Salomonsson, A.C.; Nilsson, G. Effects of organic fertilizers and urea when applied to spring wheat. Acta Agric. Scand. B Soil Plant. Sci. 1994, 44, 170-178. [CrossRef]

27. Stępień, A.; Wojtkowiak, K. Variability of mineral nitrogen contents in soil as affected by meat and bone meal used as fertilizer. Chil. J. Agric. Res. 2015, 60, 291-296. [CrossRef]

28. Nogala-Kałucka, M.; Gogolewski, M.; Jaworek, M.; Siger, A.; Szulczewska, A. Determination of some components as indicators of the quality of rapeseed produced in different regions in Poland. Oilseed Crops 2002, 23, 447-459. (In Polish)

29. Rathke, G.W.; Behrens, T.; Diepenbrock, W. Integrated nitrogen management strategies to improve seed yield, oil content and nitrogen efficiency of winter oilseed rape (Brassica napus L.): A review. Agric. Ecosyst. Environ. 2006, 117, 80-108. [CrossRef]

30. Weymann, W.; Bottcher, U.; Sieling, K.; Kage, H. Effects of weather conditions during different growth phases on yield formation of winter oilseed rape. Field Crop. Res. 2015, 173, 41-48. [CrossRef] 
31. Salomonsson, L.; Salomonsson, A.C.; Olofsson, S.; Jonsson, A. Effects of organic fertilizers and urea when applied to winter-wheat. Acta Agric. Scand. B Soil Plant. Sci. 1995, 45, 171-180. [CrossRef]

32. Stępien, A.; Wojtkowiak, K. Effect of meat and bone meal and effective microorganisms on content and composition of protein in crops. Part I. Spring wheat. Acta Sci. Pol. Agric. 2011, 10, 143-152. (In Polish)

33. Mondini, C.; Cayuela, M.L.; Sinicco, T.; Sanchez-Monedero, M.A.; Bertolone, E.; Bardi, L. Soil application of meat and bone meal. Short-term effects on mineralization dynamics and soil biochemical and microbiological properties. Soil Biol. Biochem. 2008, 40, 462-474. [CrossRef]

34. Bohacz, J.; Korniłłowicz-Kowalska, T. Influence of keratin-bark and keratin-bark-straw composts on properties of selected soils. Part II. Chemical properties. Zesz. Probl. Post. Nauk. Rol. 2005, 506, 65-76. (In Polish)

35. Bassirirad, H. Kinetics of nutrient uptake by roots: Responses to global changes. New Phytol. 2000, 147, 155-169. [CrossRef]

36. Delin, S.; Engstrom, L. Timing of organic fertiliser application to synchronise nitrogen supply with crop demand. Acta Agric. Scand. B Soil Plant. Sci. 2010, 60, 78-88. [CrossRef] 